\title{
Parents' Involvement in High-Stakes Language Assessment: A Review of Test Impact on Parent Behavior
}

\author{
Jing Zhang ${ }^{1}$ \\ ${ }^{1}$ Department of Linguistics, Sophia University, Yotsuya Campus, 7-1 Kioi-cho, Chiyoda-Ku, Tokyo, 102-8554, \\ Japan \\ Correspondence: Jing Zhang, Department of Linguistics, Sophia University, Yotsuya Campus, 7-1 Kioi-cho, \\ Chiyoda-Ku, Tokyo, 102-8554, Japan.
}

Received: November 2, 2021

Accepted: November 16, 2021

Online Published: November 19, 2021

doi: $10.5539 /$ elt.v14n12p55

URL: https://doi.org/10.5539/elt.v14n12p55

\begin{abstract}
This paper reviews a total of 20 empirical research studies concerning parents' behavior under the context of high-stakes language assessment, aiming to reveal the impact of the assessment on parents' behavior. The results show that (1) parents are typically involved in high-stakes language assessment process; (2) their involvement practice includes general (such as hiring tutors for children) and extreme involvement behavior (such as participating in movement against high-stakes testing); (3) no unanimous conclusion is reached concerning the effectiveness of parents' involvement in high-stakes language assessment; (4) multiple factors that affect parents' involvement in high-stakes language assessment are identified, including parents' perceptions of tests, their educational background, and the time they spend with their children. This study concludes that tests might influence the ways parents are involved in children's education. However, not all parents might be influenced by testing, and testing might have a positive impact on some parents but a negative impact on others. This synthesis has several practical implications. Firstly, it indicates that parents' involvement behavior in the context of high-stakes language assessment deserves to be further investigated. Secondly, it points that various intervention programs should be provided for parents to help them better support their children's learning and test preparation. The paper also offers several suggestions for future research.
\end{abstract}

Keywords: high-stakes language assessment, test impact, parents' involvement

\section{Introduction}

A wealth of research has shown that parents are typically engaged in their children's learning. This behavior is called parent academic involvement or parents' involvement (PI) in children's education, which is defined as "parents' interactions with schools and with their children to promote academic success" (Hill \& Tyson, 2009, p. 741). Mounting evidence suggests that PI is effective for advancing student academic achievement, and the effect sizes are small to moderate (e.g., Fan \& Chen, 2001; Hill \& Tyson, 2009). Although many researchers are committed to exploring the factors that affect PI (e.g., Hoover-Dempsey \& Sandler, 1995, 1997), few have treated assessment as an essential variable. It seems that PI has been widely investigated within the non-assessment field (Cheng, Andrews, \& Yu, 2010; Dawadi, 2019).

Similarly, in the field of language assessment, studies investigating the impact of assessment on parents are scarce, specifically in what ways parents help their children to be successful in high-stakes assessments (Cheng et al., 2010; Tsagari \& Cheng, 2017). To date, most of the existing research focused on parent perceptions of language tests (e.g., Desforges, Hughes, \& Holden, 1994; Scott, 2007; Vandergrift, 2015) rather than parent behavior that is likely to be affected by assessments.

It is essential to explore test (Note 1) impact on PI behavior (Cheng et al., 2010; Dawadi, 2019) for several reasons. First, not only are parents one of the key test stakeholders (Scott, 2007), but they know their children best (Martínez, Martínez, R., \& Pérez, 2004; Rutland \& Hall, 2013). Second, tests might have an impact on PI in assessment - the behavior parents adopt to improve their children's academic achievement (Cheng et al., 2010). Third, it is argued that PI in language assessment might help children succeed in the tests (Reta, 2017). Yet, scarce empirical evidence has been provided to support the prediction that tests affect PI in assessment, which in turn impacts students' academic attainment. 
Despite the importance of the topic, however, no systematic review of the literature has been conducted concerning test impact on PI. The review by Harris (2015) was the only one that can be found until now, but her study focused on parents' understandings of and attitudes towards testing rather than parent behavior. This research attempts to fill this void by conducting a synthesis of test impact on parent behavior, interpreting parents' involvement behavior under the context of high-stakes language assessment. In so doing, the following research questions are addressed:

RQ1: Are parents involved in the assessment process? If yes, how are they involved?

RQ2: Is parents' involvement behavior in the assessment process effective for promoting students' academic achievement? If yes, what is the effect size?

RQ3: What factors affect parents' involvement behavior in the assessment process?

This synthesis begins by describing the procedure of searching, screening, and analyzing literature. Then, it reports the findings and discusses the test impact on parents' behavior. Finally, implications are expounded.

\section{Methods}

This research synthesis conducted a literature search in major electronic databases such as the Educational Resources Information Center (ERIC) and Google Scholar, using the following keywords: parent(s) and assessment(s)/ test(s)/testing/ high-stakes test(s)/ high-stakes testing, the impact/ consequence/ effect of high-stake assessment(s) /test(s)/ testing on parent(s), involving parents in children's assessment(s)/test(s)/ testing, and parents' involvement in assessment(s)/ test(s)/ testing/ high-stakes test(s). Finally, 33 research studies were identified, which were carefully reviewed and screened based on the following criteria.

- This synthesis mainly focused on high-stakes language assessments, particularly English tests. Given the small number of studies specifically centering on the impact of high-stakes language assessment on parents, this synthesis also considered the studies investigating the entire high-stakes assessment program that includes language assessment;

- Due to the limited number of empirical research, this synthesis was not limited to peer-reviewed publications (Harris, 2015). However, in order to guarantee the reliability of the results, this synthesis only considered the studies with rigorous research design, which means that the studies reported how data were collected and analyzed, the research findings were consistent with the data collected, and the conclusions were aligned with the research findings (Henderson \& Mapp, 2002);

- For the sake of focus, this synthesis did not include the assessment designed for special education.

Finally, 20 studies were included and they represented the following three categories:

- Research on parents' general involvement behavior $(\mathrm{N}=8)$;

- Research on parents' extreme involvement behavior $(\mathrm{N}=7)$;

- Research on parent intervention programs $(\mathrm{N}=5)$.

These studies are listed in Tables 1-3. The main information retrieved from these studies included macro- and micro-context (educational background and target tests), research type (qualitative or quantitative; longitudinal or cross-sectional), methods of data collection and analysis, parent participants, sample size, research purpose, main findings, the content of the parent intervention program, effects and effect sizes reported.

Table 1. Research on Parents' General Involvement Behavior

\begin{tabular}{|c|c|c|c|c|c|c|c|}
\hline Literature & $\begin{array}{l}\text { Macro- and } \\
\text { Micro-context }\end{array}$ & $\begin{array}{l}\text { Research } \\
\text { Type }\end{array}$ & $\begin{array}{l}\text { Data Collection } \\
\text { and Sample Size }\end{array}$ & Data Analysis & Parent Participants & Purpose & $\begin{array}{l}\text { Main Findings (focused } \\
\text { on parents' behavior) }\end{array}$ \\
\hline $\begin{array}{l}\text { Barksdale } \\
\text {-Ladd \& } \\
\text { Thomas } \\
(2000)\end{array}$ & $\begin{array}{l}\text { Elementary and } \\
\text { secondary } \\
\text { education in the } \\
\text { US; } \\
\text { State mandated } \\
\text { standardized tests }\end{array}$ & $\begin{array}{l}\text { Qualitative } \\
\text { research }\end{array}$ & $\begin{array}{l}\text { Semi-structured } \\
\text { interviews and } \\
\text { focus groups }(\mathrm{N}= \\
20)\end{array}$ & $\begin{array}{l}\text { Identifying } \\
\text { categories; } \\
\text { Coding }\end{array}$ & $\begin{array}{l}\text { Parents whose } \\
\text { children attended } \\
\text { school /university } \\
\text { partnership schools; } \\
10 \text { parents from a } \\
\text { Southern State and } \\
\text { another } 10 \text { parents } \\
\text { from a Northern } \\
\text { State }\end{array}$ & $\begin{array}{l}\text { To investigate (1) } \\
\text { what parents know } \\
\text { about education } \\
\text { policies and how } \\
\text { teachers prepare } \\
\text { students for tests; (2) } \\
\text { how parents prepare } \\
\text { their children for } \\
\text { tests; (3) how parents } \\
\text { perceive the value of } \\
\text { the tests and their } \\
\text { children's schools }\end{array}$ & $\begin{array}{l}\text { Parents from the Southern } \\
\text { state did not prepare their } \\
\text { children for the test, while } \\
\text { parents from the Northern } \\
\text { state did. }\end{array}$ \\
\hline
\end{tabular}




\begin{tabular}{|c|c|c|c|c|c|c|}
\hline Literature & $\begin{array}{l}\text { Macro- and } \\
\text { Micro-context }\end{array}$ & $\begin{array}{l}\text { Research } \\
\text { Type }\end{array}$ & $\begin{array}{l}\text { Data Collection } \\
\text { and Sample Size }\end{array}$ & Data Analysis & Parent Participants & Purpose \\
\hline $\begin{array}{l}\text { Ferman } \\
(2004)\end{array}$ & $\begin{array}{l}\text { Secondary } \\
\text { education in Israel; } \\
\text { EFL National Oral } \\
\text { Matriculation Test }\end{array}$ & $\begin{array}{l}\text { Mixed } \\
\text { method } \\
\text { research }\end{array}$ & $\begin{array}{l}\text { A student } \\
\text { questionnaire }(\mathrm{N} \\
=\quad 120) \text {; } \\
\text { Structured } \\
\text { interviews with } \\
\text { teachers }(\mathrm{N}=18) \text {; } \\
\text { Open interviews } \\
\text { with regional } \\
\text { inspectors }(\mathrm{N}= \\
\text { 3). }\end{array}$ & $\begin{array}{l}\text { Qualitative } \\
\text { data: Using the } \\
\text { variables } \\
\text { established in } \\
\text { the } \\
\text { questionnaires; } \\
\text { Quantitative } \\
\text { data: Using } \\
\text { descriptive } \\
\text { statistics }\end{array}$ & $\begin{array}{l}\text { EFL teachers } \\
\text { (Grades } 11 \text { to 12) } \\
\text { and students with } \\
\text { different ability } \\
\text { levels (Grade 12), } \\
\text { from three different } \\
\text { types of high } \\
\text { schools; No parent } \\
\text { participant }\end{array}$ & $\begin{array}{l}\text { To investigate } \\
\text { whether the EFL Oral } \\
\text { matriculation test has } \\
\text { washback on the } \\
\text { educational } \\
\text { processes, } \\
\text { participants, and the } \\
\text { products of teaching } \\
\text { and learning }\end{array}$ \\
\hline
\end{tabular}

\section{Martínez, \\ Martínez, Elementary \\ R \& education in Spain; \\ Pérez School academic \\ (2004) \\ Mixed methods research}

Cheng et al. (2010) education in Hong Kong;

School-based assessment (SBA)
A questionnaire, including closed and open-ended questions $(\mathrm{N}=$ 188)

\section{Quantitative}

data:

Descriptive

statistics;

Qualitative

data: Not reported.
Descriptive analysis; Exploratory factor analysis; Independent sample $t$-test, paired sample $t$-test, and multiple regressions
Parents Secondary students from two schools; Mostly from low-middleor lower-class families questionnaire $(\mathrm{N}$ quantitative $\quad=315$ ) research
Elementary education

Holyk

(2011) Canada; Provincial Foundation Skills Assessment and classroom assessment
Semi-structured

Qualitative research

$$
\text { 18) }
$$

Thematic analysis interviews $(\mathrm{N}=$

Parents of Grade 4 students within the Lake Babine Nation
Parents of third graders from eight Spanish schools located in both urban and rural areas of the region of Asturias in Spain
To investigate parents' perceptions of school assessment
To parents' of and involvement in assessment parents' and students' perceptions of SBA and the impact of SBA on teaching and learning; (2) the relationship between parents' perceptions and students' perceptions
To investigate (1)

Main Findings (focused on parents' behavior)

(1) Parents participated in the testing process, which was demonstrated by their urging children to learn for the test. (2) Parents hired tutors to help their children prepare for the test. (3) Parents whose children were at average ability level tended to employ more tutors for their children.

(1) Parents thought that the assessment provided useful information about their children's learning and in turn helped them better involve in their children's learning. (2) Parents involvement strategies related to assessment included communicating with teachers, helping with homework,

encouragement, helping their children analyze the reason why they did not succeed in the assessment, and hiring a private tutor.

(1) Parents' level of education and the time they spent with their children had a positive effect on their support for their children in SBA. (2) Parents' perceived knowledge about SBA had a positive effect on their support for their children in SBA. (3) When parents perceived that SBA could be helpful for their children's learning, they would be more supportive of their children's SBA-related learning.

Parents were involved in the assessment process by taking these strategies: helping with homework, communication with their children and teachers. Communicating with teachers was an effective way to learn assessment knowledge.

Parents of grade 10 To hear parents' students (age voices and explore 14-16); Most from their perceptions of low socioeconomic SEE and their support status families
(1) All parents perceived that test preparation was a shared responsibility among students, parents, and teachers so that
Thematic method semi-structured analysis research 


\begin{tabular}{|c|c|c|c|c|c|c|c|}
\hline Literature & $\begin{array}{l}\text { Macro- and } \\
\text { Micro-context }\end{array}$ & $\begin{array}{l}\text { Research } \\
\text { Type }\end{array}$ & $\begin{array}{l}\text { Data Collection } \\
\text { and Sample Size }\end{array}$ & Data Analysis & Parent Participants & Purpose & $\begin{array}{l}\text { Main Findings (focused } \\
\text { on parents' behavior) }\end{array}$ \\
\hline $\begin{array}{l}\text { Eizadirad } \\
(2020)\end{array}$ & $\begin{array}{l}\text { Elementary } \\
\text { education in } \\
\text { Canada; Education } \\
\text { Quality and } \\
\text { Accountability } \\
\text { Office standardized } \\
\text { test (EQAO } \\
\text { standardized tes) }\end{array}$ & $\begin{array}{l}\text { Qualitative } \\
\text { research }\end{array}$ & $\begin{array}{lr}\text { pre-and } & \text { post- } \\
\text { SEE surveys and } \\
\text { interviews } & \text { with } \\
\text { students; } & \text { Case } \\
\text { study } & \text { with } \\
\text { students } & \end{array}$ & $\begin{array}{l}\text { Thematic } \\
\text { analysis }\end{array}$ & $\begin{array}{l}\text { Parents of grade } 3 \\
\text { elementary school } \\
\text { students, who } \\
\text { identified } \\
\text { themselves and } \\
\text { their children as } \\
\text { racialized }\end{array}$ & $\begin{array}{l}\text { To hear racialized } \\
\text { parents' voices } \\
\text { regarding the impact } \\
\text { of the EQAO } \\
\text { standardized test on } \\
\text { their children, their } \\
\text { identities, and life } \\
\text { experience }\end{array}$ & $\begin{array}{l}\text { parents tried their best to } \\
\text { provide support for their } \\
\text { children's test } \\
\text { preparation. (2) The } \\
\text { strategies they used to } \\
\text { involve in their children's } \\
\text { test preparation included } \\
\text { providing learning } \\
\text { conditions at home, } \\
\text { cooperating with } \\
\text { neighbors and relatives, } \\
\text { sending their children to } \\
\text { cramming courses } \\
\text { provided by children's } \\
\text { school teachers, } \\
\text { controlling children's } \\
\text { amusement time, helping } \\
\text { with homework, teaching } \\
\text { test-taking strategies, and } \\
\text { sharing test-taking } \\
\text { experience. The last three } \\
\text { strategies were only used } \\
\text { by parents who had high } \\
\text { levels of education. (3) As } \\
\text { the exam was imminent, } \\
\text { parents would adopt } \\
\text { different thest } \\
\text { developing strategies. (4) } \\
\text { Although parents were } \\
\text { positively involved in } \\
\text { their children's test } \\
\text { preparation, their } \\
\text { children's performance in } \\
\text { SEE was bad. the } \\
\text { Parents were involved in } \\
\text { their children's test } \\
\text { preparation before the } \\
\text { testing week, and the } \\
\text { involvement strategies } \\
\text { practice questions. }\end{array}$ \\
\hline
\end{tabular}

Table 2. Research on Parents' Extreme Involvement Behavior

\begin{tabular}{|c|c|c|c|c|c|c|c|}
\hline Literature & $\begin{array}{l}\text { Macro- and } \\
\text { Micro-context }\end{array}$ & Research Type & $\begin{array}{l}\text { Data Collection } \\
\text { and Sample Size }\end{array}$ & $\begin{array}{l}\text { Data } \\
\text { Analysis }\end{array}$ & $\begin{array}{l}\text { Parent } \\
\text { Participants }\end{array}$ & Purpose & Main Findings \\
\hline $\begin{array}{l}\text { Pizmony-Levy } \\
\& \quad \text { Saraisky } \\
(2016)\end{array}$ & $\begin{array}{l}\text { The high-stakes } \\
\text { standardized } \\
\text { testing climate in } \\
\text { the US; Federally } \\
\text { mandated } \\
\text { educational } \\
\text { assessments }\end{array}$ & $\begin{array}{l}\text { Cross-sectional } \\
\text { quantitative } \\
\text { research }\end{array}$ & $\begin{array}{l}\text { Online-question } \\
\text { naire }(\mathrm{N}=1641)\end{array}$ & $\begin{array}{l}\text { Descriptive } \\
\text { statistics; } \\
\text { multivariate } \\
\text { analysis } \\
\text { (logistic and } \\
\text { multinomial } \\
\text { logistic } \\
\text { regression) }\end{array}$ & $\begin{array}{l}\text { Parents } \\
\text { participating in } \\
\text { the movement: } \\
\text { Largely white } \\
\text { women, } \\
\text { married, high } \\
\text { socioeconomic } \\
\text { status, highly } \\
\text { educated, } \\
\text { parents of } \\
\text { school-age } \\
\text { children }\end{array}$ & $\begin{array}{l}\text { To investigate } \\
\text { who } \\
\text { participated in } \\
\text { the } \\
\text { movement, } \\
\text { why and how } \\
\text { they } \\
\text { participated } \\
\text { in, and what } \\
\text { did they think } \\
\text { about } \\
\text { education } \\
\text { policy }\end{array}$ & $\begin{array}{l}\text { (1) Most of the Opt-Out } \\
\text { movement participants were } \\
\text { parents of public-school students. } \\
\text { (2) Social media played a major } \\
\text { role in mobilizing participants. (3) } \\
\text { The reason for participating in the } \\
\text { movement was not just their } \\
\text { opposition to high-stakes } \\
\text { standardized tests. Some of the } \\
\text { parents disagreed with teaching to } \\
\text { the test and judged teachers' } \\
\text { performance by using students' } \\
\text { scores on high-stakes tests. }\end{array}$ \\
\hline
\end{tabular}




\begin{tabular}{|c|c|c|c|c|c|c|}
\hline Literature & $\begin{array}{l}\text { Macro- and } \\
\text { Micro-context }\end{array}$ & Research Type & $\begin{array}{l}\text { Data Collection } \\
\text { and Sample Size }\end{array}$ & $\begin{array}{l}\text { Data } \\
\text { Analysis }\end{array}$ & $\begin{array}{l}\text { Parent } \\
\text { Participants }\end{array}$ & Purpose \\
\hline $\begin{array}{l}\text { Abraham, } \\
\text { Wassell, Luet, } \\
\text { \&Vitalone-Ra } \\
\text { carro, (2018) }\end{array}$ & $\begin{array}{l}\text { The high-stakes } \\
\text { standardized } \\
\text { testing climate in } \\
\text { the US; The } \\
\text { Partnership for } \\
\text { Assessment of } \\
\text { Readiness for } \\
\text { College and } \\
\text { Careers (PARCC) } \\
\text { exam }\end{array}$ & $\begin{array}{l}\text { Qualitative } \\
\text { research }\end{array}$ & $\begin{array}{l}\text { Participant } \\
\text { observation, } \\
\text { open-ended } \\
\text { online-question } \\
\text { naire }(\mathrm{N}=242) \text {, } \\
\text { focus group } \\
\text { interviews ( } \mathrm{N}= \\
\text { 8), and refusal } \\
\text { letters }\end{array}$ & $\begin{array}{l}\text { Thematical } \\
\text { coding; } \\
\text { Critical } \\
\text { discourse } \\
\text { analysis }\end{array}$ & $\begin{array}{l}\text { Parents } \\
\text { participating in } \\
\text { the Opt-Out } \\
\text { movement } \\
\text { (Mostly white, } \\
\text { middle-class } \\
\text { females with } \\
\text { higher } \\
\text { education) }\end{array}$ & $\begin{array}{l}\text { To investigate } \\
\text { why and how } \\
\text { parents } \\
\text { refused the } \\
\text { exam }\end{array}$ \\
\hline
\end{tabular}

The high-stakes

Schroeder,

Currin,

McCardle

(2016) standardized

\& testing climate in the US; The

high-stakes standardized tests
Clayton, Bingham, \& Ecks (2019)
The high-stakes standardized testing climate in the US; English Language Arts test critical focus groups ethnographic and individual study

interviews $(\mathrm{N}=$ 6)
Using the publicly available datasets

A quantitative study employing panel data provided by the national organizations, including 1,049
Elementary

Wenham (2019) education in the UK; Standardised Assessment Tests (SATs)

\section{Qualitative} research
Semi-structured interviews $(\mathrm{N}=$ 3)
Parents (grades elementary, 545 middle, and 390 high school parents regression schools and analysis charter schools of Colorado
Parents participating in the movement:

Data analysis spiral Largely white, middle-class women
To examine the reasons and larger aims of joining the Opt-Out movement
To investigate the school-level characteristics that result in the largest number of students choosing to opt-out of the test Colorado
Main Findings

(1) Parents did not trust the PARCC exam, and they thought the PARCC was invalid. The reason for this distrust was that parents perceived the PARCC as a politically driven initiative that was not appropriate for students' educational development. (2) Parents could play a clear and authoritative role in their children's experiences with state-mandated testing through their engagement, actions, and discourses.

(1) Parents viewed the policies of using high-stakes testing to sort students, evaluate schools and teachers as "government overreach and the corporatization of public schools" (p.8). (2) They thought the educational policies were injustice to students and teachers. (3) They made use of Facebook to interact with each other and to learn more information concerning the detrimental effects of the educational policies, and they finally took action to fight against the policies.

(1) Parents whose children would perform well in the tests tended to participate in the Opt-Out movement. (2) The motivation to join the movement was their opposition to the policy of using high-stakes standardized tests to evaluate teachers. (3) Parents who were highly-informed and had higher levels of cultural capital tend to focus their children's time and energy on more important tests, such as Advanced Placement (AP) tests, and thus encourage their children to quit the state-mandated tests. On the contrary, parents who were low-informed and had lower levels of cultural capital tend to be subordinated to school decisions.

(1) Parents thought that SATs brought about a negative impact on their children's wellbeing and mental health. (2) Parents felt unsatisfied with the content, structure, and marking ways of the tests, which they thought might stifle children's love for learning. (3) Parents believed that the direct consequence brought about by the tests was trapping the teachers and students in a passive learning environment, in which the curriculum was narrowed, English and mathematics were 


\begin{tabular}{|c|c|c|c|c|c|c|c|c|}
\hline Literature & & $\begin{array}{l}\text { Macro- and } \\
\text { Micro-context }\end{array}$ & Research Type & $\begin{array}{l}\text { Data Collection } \\
\text { and Sample Size }\end{array}$ & $\begin{array}{l}\text { Data } \\
\text { Analysis }\end{array}$ & $\begin{array}{l}\text { Parent } \\
\text { Participants }\end{array}$ & Purpose & Main Findings \\
\hline $\begin{array}{l}\text { Schroeder, } \\
\text { Currin, } \\
\text { McCardle } \\
(2020 \mathrm{a})\end{array}$ & $\&$ & $\begin{array}{l}\text { The high-stakes } \\
\text { standardized } \\
\text { testing climate in } \\
\text { the US; The } \\
\text { high-stakes } \\
\text { standardized tests }\end{array}$ & $\begin{array}{l}\text { A critical } \\
\text { ethnographic } \\
\text { study }\end{array}$ & $\begin{array}{l}\text { Online-questi } \\
\text { onnaire ( } \mathrm{N}= \\
208), \text { focus } \\
\text { groups and } \\
\text { individual } \\
\text { interviews ( } \mathrm{N} \\
=6)\end{array}$ & $\begin{array}{l}\text { Data analysis } \\
\text { spiral }\end{array}$ & $\begin{array}{l}\text { Parents } \\
\text { participating in } \\
\text { the movement: } \\
\text { Largely white, } \\
\text { middle-class } \\
\text { women }\end{array}$ & $\begin{array}{l}\text { To investigate } \\
\text { why parents } \\
\text { joined the } \\
\text { Opt-Out } \\
\text { movement }\end{array}$ & $\begin{array}{l}\text { over-emphasized, as well as the } \\
\text { test preparation activities were } \\
\text { conducted repetitively. } \\
\text { (1) Parents who joined the } \\
\text { Opt-Out movements firmly } \\
\text { believe that refusing tests could } \\
\text { "stop the overuse and misuse of } \\
\text { high-stakes tests" (p. 142). (2) } \\
\text { Parents thought that high-stakes } \\
\text { testing had a negative effect on } \\
\text { their children both mentally and } \\
\text { physically, and ultimately led to } \\
\text { their children's "lack of } \\
\text { engagement and joy in learning" } \\
\text { (p. 148). (3) Their perceptions of } \\
\text { high-stakes testing originated } \\
\text { from the observation of their } \\
\text { children's behavior before and } \\
\text { after the test. However, although } \\
\text { parents refused high-stakes tests, } \\
\text { they support teachers using } \\
\text { multiple assessments to measure } \\
\text { students' learning and the } \\
\text { assessments should be dominated } \\
\text { by teachers because teachers are } \\
\text { professionals. (4) Parents desired } \\
\text { dialogue with teachers, schools, } \\
\text { administrators, and policymakers. }\end{array}$ \\
\hline $\begin{array}{l}\text { Schroeder, } \\
\text { Currin, } \\
\text { McCardle } \\
(2020 b)\end{array}$ & $\&$ & $\begin{array}{l}\text { The high-stakes } \\
\text { standardized } \\
\text { testing climate in } \\
\text { the US; The } \\
\text { high-stakes } \\
\text { standardized tests }\end{array}$ & $\begin{array}{l}\text { Critical digital } \\
\text { ethnographic } \\
\text { research }\end{array}$ & $\begin{array}{l}\text { Online-quest } \\
\text { ionnaire }(\mathrm{N}= \\
208), \text { focus } \\
\text { groups and } \\
\text { individual } \\
\text { interviews } \\
(\mathrm{N}=6)\end{array}$ & $\begin{array}{l}\text { Grounded } \\
\text { theory }\end{array}$ & $\begin{array}{l}\text { Parents } \\
\text { participating in } \\
\text { the movement: } \\
\text { Largely white, } \\
\text { middle-class } \\
\text { women }\end{array}$ & $\begin{array}{l}\text { To hear the } \\
\text { voice the } \\
\text { Opt-Out } \\
\text { Movement } \\
\text { members and } \\
\text { to examine } \\
\text { their voices } \\
\text { through a lens } \\
\text { of morality }\end{array}$ & $\begin{array}{l}\text { Parents and teachers were } \\
\text { experiencing injustice. Their } \\
\text { voices were dismissed and even } \\
\text { despised, although they are key } \\
\text { stakeholders, which resulted in } \\
\text { their moral injury. }\end{array}$ \\
\hline
\end{tabular}

Table 3. Research on Parent Intervention Programs

\begin{tabular}{|c|c|c|c|c|c|c|c|c|}
\hline Literature & $\begin{array}{l}\text { Macro- and } \\
\text { micro-context }\end{array}$ & Participants & $\begin{array}{l}\text { Data } \\
\text { Collection and } \\
\text { Sample Size }\end{array}$ & Data Analysis & The Intervention Program & Purpose & Main Findings & Effect Sizes \\
\hline $\begin{array}{l}\text { Chrispeels } \\
\& \quad \text { Rivero } \\
(2001)\end{array}$ & $\begin{array}{l}\text { Elementary } \\
\text { education in the } \\
\text { US; No specific } \\
\text { test }\end{array}$ & $\begin{array}{l}\text { Parents (mostly } \\
\text { Latino) who } \\
\text { attended the } \\
\text { program; were } \\
\text { from two } \\
\text { elementary } \\
\text { schools in a city } \\
\text { of California, } \\
\text { which were } \\
\text { ranked among } \\
\text { the } \\
\text { lowest-performi } \\
\text { ng in the region. }\end{array}$ & $\begin{array}{l}\text { Prequestionnai } \\
\text { re and } \\
\text { postquestionna } \\
\text { ire }(\mathrm{N}=95) \text {; } \\
\text { Observation; } \\
\text { Video-taping } \\
\text { of all sessions; } \\
\text { In-depth } \\
\text { interviews ( } \mathrm{N} \\
=19) \text {; Review } \\
\text { of artifacts }\end{array}$ & $\begin{array}{l}\text { Taxonomic } \\
\text { analysis; } \\
\text { Descriptive } \\
\text { statistics; } t \text {-test }\end{array}$ & $\begin{array}{l}\text { The Parent Institute for } \\
\text { Quality Education (PIQE) } \\
\text { program provides } \\
\text { information about } \\
\text { education policy to parents, } \\
\text { especially low-income } \\
\text { parents or recent } \\
\text { immigrants to the US. } \\
\text { Specifically, this program } \\
\text { teaches parents the current } \\
\text { system of testing, how the } \\
\text { educational system is } \\
\text { organized and decisions are } \\
\text { made, the academic } \\
\text { standards and expectations } \\
\text { in Arizona, how to check } \\
\text { their children's learning } \\
\text { progress, and the } \\
\text { importance of reading for } \\
\text { academic success. }\end{array}$ & $\begin{array}{l}\text { To investigate } \\
\text { the effect of the } \\
\text { program on } \\
\text { "immigrant } \\
\text { parents' sense of } \\
\text { place in their } \\
\text { children's } \\
\text { education" (p. } \\
\text { 121) }\end{array}$ & $\begin{array}{l}\text { (1) The program raised } \\
\text { the parents' awareness } \\
\text { of the importance of } \\
\text { grades. (2) The } \\
\text { program helped } \\
\text { parents have a better } \\
\text { understanding of the } \\
\text { American educational } \\
\text { system. (3) After the } \\
\text { program, parents } \\
\text { initiated more contact } \\
\text { with teachers, } \\
\text { interacted with their } \\
\text { children more } \\
\text { positively, adopted } \\
\text { more home-based } \\
\text { involvement, } \\
\text { participated in PIQE } \\
\text { and other workshops } \\
\text { more actively, and } \\
\text { served as advocates }\end{array}$ & Not reported. \\
\hline
\end{tabular}




$\begin{array}{llllll}\text { Literature } & \begin{array}{l}\text { Macro- and } \\ \text { micro-context }\end{array} & \text { Participants } & \begin{array}{l}\text { Data } \\ \text { Collection and } \\ \text { Sample Size }\end{array} & \text { Data Analysis } \quad \text { The Intervention Program Purpose } \quad \text { Main Findings } & \text { Effect Sizes }\end{array}$

more positively.

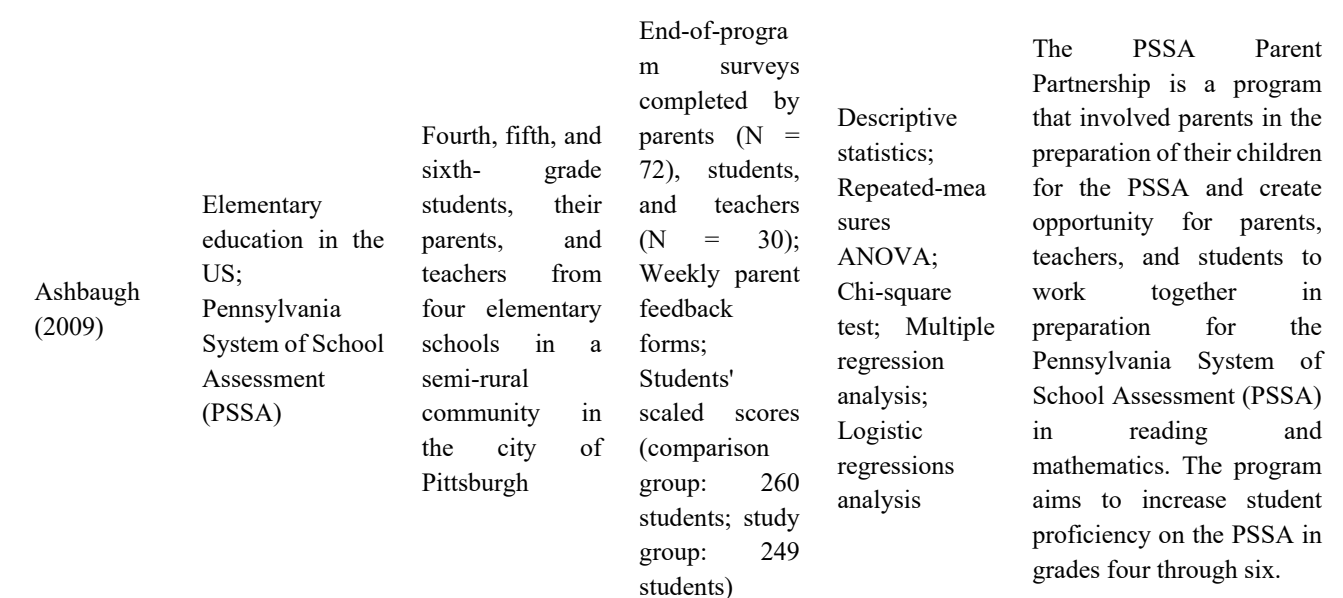

Elementary

Auerbach \& education in the Collier US; California (2012) Standards Test (CST)

The high-stakes standardized testing climate in the US; No specific test writing. 80)

\begin{tabular}{|c|c|c|c|}
\hline $\begin{array}{l}\text { Latino parents } \\
\text { (mostly }\end{array}$ & $\begin{array}{l}\text { Observations } \\
\text { of planning }\end{array}$ & & \\
\hline low-income) of & meetings and & & Promoting \\
\hline elementary & parent & & Success is a parent training \\
\hline students & workshops, & & program \\
\hline four schools in & bilingual & & accountability goals, which \\
\hline Los Angeles; & parent focus & $\begin{array}{l}\text { Constant } \\
\text { comparative }\end{array}$ & $\begin{array}{l}\text { provides information about } \\
\text { standardized testing and }\end{array}$ \\
\hline $\begin{array}{l}65 \% \text { spoke } \\
\text { Spanish at home. }\end{array}$ & $\begin{array}{l}\text { groups, } \\
\text { semi-structure }\end{array}$ & method; & teaches parents reading \\
\hline $\begin{array}{l}\text { Their children } \\
\text { were }\end{array}$ & $\begin{array}{l}\mathrm{d} \text { interviews } \\
\text { with staff, a }\end{array}$ & Coding & $\begin{array}{l}\text { skills, particularly word } \\
\text { analysis skills, to improve }\end{array}$ \\
\hline low-performance & parent & & elementary students' test \\
\hline $\begin{array}{l}\text { English language } \\
\text { learners on CST }\end{array}$ & $\begin{array}{l}\text { questionnaire, } \\
\text { and document }\end{array}$ & & $\begin{array}{l}\text { scores in low-achieving } \\
\text { schools. }\end{array}$ \\
\hline
\end{tabular}

- reading and review $(\mathrm{N}=$

Two parents' cohorts: Cohort 1 included parents who enrolled in and completed the RAD program in Fall 2011; Cohort 2 included parents who enrolled in and completed the RAD program in Spring 2012. All parents were from Phoenix, Arizona, area elementary, middle, and high schools during the 2011-2012

academic year.
Realizing the American Dream (RAD) parent education program aims to enhance Latino parents' involvement behaviors. It teaches parents the fundamentals of American schooling, the importance and strategies for cooperating with schools, and strategies for involving children's education at home. It provides parents with information about standardized testing, such as academic standards and performance requirements.
(1) The program increased students' academic achievement and proficiency on the PSSA and facilitated communication between home and school. (2) Parents held positive To investigate attitudes towards the the effect of the program because it program on (1) helped parents become student familiar with the format proficiency on and expectations of the the PSSA and PSSA, which in turn their academic helped the student and achievement; (2) parent prepare for the communication test. (3) Parents thought between teachers the program made them and parents realize the importance of the exam. (4) Parents perceived the program as a good opportunity to work with their children and to know their children's capabilities, strengths, weaknesses.

The program (1) did not promote students' academic

achievements.

(2) (1) the effect of the program on students'

academic

achievement and family

engagement; (2) educators' and parents' perceptions of the program

increased parents' involvement at home and in school and their knowledge about reading skills and use of new literacy strategies. (3) made parents more aware of testing and school expectations.

Not reported.
To investigate (1) the effect of the program on parents'

knowledge,

belief and behavior; (2) the predicting factors for the changes; (3) whether the program was implemented with fidelity across multiple sites
(1) The program had a significant and positive effect on parents knowledge, beliefs, and involvement behaviors.

Factors predicting the changes after the program included knowledge and beliefs, prior behaviors and beliefs, and family income. post-program

The program had large effect sizes on parents' knowledge

(Cohort 1: $\mathrm{d}=$ 1.13; Cohort 2: d $=1.29$ ), modest effect sizes on parents' beliefs (Cohort 1: d $=.20$; Cohort 2: $\mathrm{d}=.48$ ), and moderate effect sizes on parents' school sites in Cohort 1) involvement

behaviors

(Cohort 1: d $=.73$; Cohort 2 : $\mathrm{d}=.72$ ). 


\begin{tabular}{|c|c|c|c|c|c|c|c|c|}
\hline Literature & $\begin{array}{l}\text { Macro- and } \\
\text { micro-context }\end{array}$ & Participants & $\begin{array}{l}\text { Data } \\
\text { Collection and } \\
\text { Sample Size }\end{array}$ & Data Analysis & The Intervention Program & Purpose & Main Findings & Effect Sizes \\
\hline $\begin{array}{l}\text { Araque, } \\
\text { Wietstock, } \\
\text { Cova, \& } \\
\text { Zepeda } \\
(2017)\end{array}$ & $\begin{array}{l}\text { Elementary } \\
\text { education in the } \\
\text { US; State } \\
\text { mandated } \\
\text { standardized test }\end{array}$ & $\begin{array}{l}\text { Latino parents } \\
\text { from two } \\
\text { elementary and } \\
\text { two intermediate } \\
\text { schools in Santa } \\
\text { Ana Unified } \\
\text { School District of } \\
\text { Orange County. } \\
\text { The experimental } \\
\text { group includes } 68 \\
\text { parents who } \\
\text { attended the } \\
\text { training program } \\
\text { and completed the } \\
\text { Parent Survey } \\
\text { before and after } \\
\text { the program. } \\
\text { Their children's } \\
\text { (N = 164) report } \\
\text { cards/grades for } \\
\text { two academic } \\
\text { years were also } \\
\text { collected. }\end{array}$ & $\begin{array}{l}\text { Two parent } \\
\text { surveys } \\
\text { before and } \\
\text { after the } \\
\text { program; The } \\
\text { experimental } \\
\text { group } \\
\text { included } 68 \\
\text { parents and } \\
\text { 164 students, } \\
\text { with parent } \\
\text { questionnaire } \\
\text { s and students' } \\
\text { grades } \\
\text { collected. At } \\
\text { the end of the } \\
\text { program, } \\
\text { parents' } \\
\text { written } \\
\text { comments on } \\
\text { their learning } \\
\text { experience in } \\
\text { the program. } \\
\text { The control } \\
\text { group } \\
\text { included } \\
1,628 \text { students } \\
\text { whose report } \\
\text { cards/grades } \\
\text { were also } \\
\text { collected. }\end{array}$ & $\begin{array}{l}\text { Quantitative } \\
\text { data: Paired } \\
\text { samples } t \text {-test } \\
\text { and ANOVA; } \\
\text { Qualitative } \\
\text { data: Coding }\end{array}$ & $\begin{array}{l}\text { The Ten Education } \\
\text { Commandments for } \\
\text { Parents program "teaches } \\
\text { parents the fundamentals of } \\
\text { the American education } \\
\text { system and give parents } \\
\text { tools to become more } \\
\text { actively engaged in their } \\
\text { children's education" (p. } \\
\text { 236). This program teaches } \\
\text { parents the value and } \\
\text { importance of grades, the } \\
\text { grade-level learning } \\
\text { expectancies set by the } \\
\text { Common Core State } \\
\text { Standards for K-12 students } \\
\text { in mathematics, English } \\
\text { language arts, and science, } \\
\text { and the graduation } \\
\text { requirements in California. }\end{array}$ & $\begin{array}{l}\text { To investigate } \\
\text { the effect of the } \\
\text { program on (1) } \\
\text { parents' } \\
\text { knowledge of } \\
\text { educational } \\
\text { system and } \\
\text { testing; (2) } \\
\text { parent } \\
\text { involvement in } \\
\text { children's } \\
\text { education; } \\
\text { students' } \\
\text { academic } \\
\text { achievement }\end{array}$ & $\begin{array}{l}\text { (1) The program } \\
\text { helped parents better } \\
\text { understand the } \\
\text { educational system } \\
\text { and testing, which } \\
\text { resulted in greater PI. } \\
\text { (2) Intermediate } \\
\text { school students' } \\
\text { parents who } \\
\text { participated in the } \\
\text { program had children } \\
\text { who significantly } \\
\text { increased from Basic } \\
\text { to Proficient levels in } \\
\text { math, language arts, } \\
\text { and science, whereas } \\
\text { parents who did not } \\
\text { participate in the } \\
\text { program had children } \\
\text { who remained at a } \\
\text { Basic level in all } \\
\text { subjects. }\end{array}$ & Not reported. \\
\hline
\end{tabular}

\section{Results}

The next section presents the results of the analysis, which shows parents' involvement behavior under the context of high-stakes language assessment. The magnitudes of associations between constructs and effect sizes are reported based on Cohen's (1988) benchmark.

\subsection{The Answer to $R Q 1$}

RQ1 asks "are parents involved in the assessment process? If yes, how are they involved?" Tables 1 and 2 illustrate the studies investigating parents' involvement in the assessment process. All of the 20 studies provided empirical evidence for parents involved in testing, indicating that parents do involve in the high-stakes language assessment process and they are involved in two ways: general and extreme involvement behavior.

\subsubsection{Parents' General Involvement Behavior: Parent Involvement in Assessment at Home}

As shown in Table 1, the PI behavior under the context of high-stakes language assessment reported in the literature largely overlaps with the PI behavior identified in general parental involvement literature. For example, encouragement (e.g., Eizadirad, 2020; Martínez et al., 2004), communication (Eizadirad, 2020; Holyk, 2011; Martínez et al., 2004), providing learning conditions at home, and controlling children's amusement time (Dawadi, 2019, 2020), and helping with homework (Barksdale-Ladd \& Thomas, 2000; Dawadi, 2019, 2020; Holyk, 2011; Martínez et al., 2004).

Except for these general PI practices, some studies reported strategies parents specifically employed to help children prepare for the test. Namely, without a test, parents might not take these strategies, which thus can be named parent involvement in test preparation (PI_TP). A range of PI_TP strategies are identified in the existing literature:

- Purchasing test-related materials, such as examination guidance books (Barksdale-Ladd \& Thomas, 2000); 
- Sending children to cram schools or hiring tutors (Dawadi, 2019, 2020; Ferman, 2004; Martínez et al., 2004);

- Teaching children test-taking strategies and sharing the test-taking experience with children (Dawadi, 2019, 2020);

- Urging children to learn for the test (Dawadi, 2019, 2020; Ferman, 2004);

- Cooperating with neighbors and relatives to support children' test preparation (Dawadi, 2019, 2020);

- Helping children analyze the reason why they did not succeed in the test (Martínez et al., 2004);

- Familiarizing children with test questions through doing practice questions (Eizadirad, 2020).

In addition, research shows that not all parents involve in children's test preparation. Barksdale-Ladd and Thomas (2000) reported that some parents in the north state were involved in children's test preparation such as purchasing test-related materials, while other parents in the north state and all parents in the southern state did not involve in children's test preparation and they only took general PI strategies such as helping children with homework.

Further, the literature indicates that although parents prefer to involve in the assessment process by supporting their children at home (Desforges et al., 1994), researchers want more from parents. For example, Wolfendale (1998) highlighted the importance of involving parents in the assessment process and used the term "joint assessment" (p. 355) in an attempt to invite parents to be more involved in the assessment process. Fredericks and Rasinski (1990) fully described the principles and practice of involving parents in the reading assessment process and illustrated two assessment tools that were successfully used in an American elementary school. Rutland and Hall (2013) proposed that parents should be not only the information consumers and informants, but also be "a collaborative member of the assessment team" (p. 8) to identify "strategies and approaches for assessment that will work best for their child" (p. 8). However, these researchers mainly focused on the assessment designed for early childhood and elementary students. Additionally, there is a lack of empirical data to prove the feasibility and effectiveness of joint assessment projects.

\subsubsection{Parents' Extreme Involvement Behavior}

In some countries that administered high-stakes accountability systems, standardized testing aroused strong opposition. Parents adopted extreme behavior to express their resistance to high-stakes standardized testing, which was described as an unwelcomed PI strategy by schools (Schroeder, Currin, \& McCardle, 2020a).

Some parents united to boycott high-stakes testing, and the Opt-Out movement in the US is a typical example. Since the administration of the No Child Left Behind Act, the US has stepped into an era of accountability via high-stakes standardized testing (Schroeder et al., 2016). The excessive power of high-stakes testing aroused public resistance, anger, and despair (Schroeder et al., 2016). Such background triggered "a grassroots coalition of opposition to high-stakes tests that are used to sort students, evaluate teachers, and rank schools" (Paladino, 2020, p. 14), and parents were leaders or main participants of the Opt-Out movement.

Most studies in Table 2 mainly explored the reason why parents participated in the Opt-Out movement. The findings of these studies indicated that the main reason for parents' opposition to high-stakes tests was that the high-stakes accountability system was not conducive to students' educational development (e.g., Abraham, Wassell, Luet, \& Vitalone-Racarro, 2018), which might harm children's physical and mental health, as well as students' learning (e.g., Schroeder et al., 2016, 2020a). In addition, parents argued that the high-stakes testing accountability system was "government overreach" (Schroeder et al., 2016, p. 8), which was unfair for both teachers and students (e.g., Pizmony-Levy \& Saraisky 2016; Schroeder et al., 2016, 2020a).

\subsection{The Answer to $R Q 2$}

RQ2 is about the effect and the effect size of parents' involvement behavior in the assessment process for promoting students' academic achievement. No direct evidence was identified to answer this question. However, the literature in Table 3 provided implicit evidence for the effectiveness of PI in language assessment. Many intervention programs offered a series of sessions to help parents familiarize themselves with tests and teach them how to support their children's test preparation. In Araque et al.'s (2017) and Ashbaugh's (2009) research, the intervention programs successfully improved PI_TP, which in turn promoted child academic achievements. On the other hand, according to Auerbach and Collier (2012), although the program increased PI_TP, children's academic attainments were not advanced. Moreover, Dawadi (2019) also provided indirect evidence that although parents tried their best to support their children's test preparation, children did not perform well on the 
test. These conflicting findings suggest that consensus has not been reached about the effectiveness of PI in the language assessment process.

\subsection{The Answer to $R Q 3$}

RQ3 asks "what factors affect parents' involvement behavior in the assessment process?" Only one study provides direct evidence to answer this question. Cheng et al.'s (2010) research showed that parents' perceptions of test quality, test knowledge, and opportunities to know about tests contributed significantly to PI TP $\left(R^{2}\right.$ $=.314$, large effect size). Parents' perceptions of test impact on students' learning motivation also made a significant contribution to PI TP $\left(R^{2}=.185\right.$, moderate effect size $)$. Further, parents' levels of education and the time they spent with their children also had a positive effect on PI_TP $\left(R^{2}=.116\right.$, small effect size).

Besides, this question can also be answered through indirect evidence. For example, the studies on the Opt-Out movement (see Table 2) indicated that parents' negative viewpoints about high-stakes assessment might impact their behavior. Martínez et al. (2004) also reported that parents' knowledge about assessment and their levels of education might affect their involvement, but they did not report the effect sizes.

\section{Discussion}

The next section firstly discusses the answers to research questions. Then, it proposes issues that deserve further investigation. Finally, the test impact on parents' behavior is delineated.

\subsection{Can the Existing Literature Fully Answer the Research Questions}

RQ 1 was fully answered. Even though parents know little about language and assessment-related information, parents are still involved in the high-stakes language assessment process (Dawadi, 2019), and the ways of involvement include general and extreme involvement. Typically, extreme involvement strategies can only be found in a few countries implementing high-stakes testing accountability systems. It might thus be concluded that the most frequently adopted PI strategies under the context of high-stakes language assessment include general PI and PI_TP strategies.

RQ 2 was not fully answered. Most studies merely described what parents did under the context of high-stakes language assessment, while few researchers specifically examined the effectiveness of PI_TP practice. Although some studies provided indirect evidence indicating the effectiveness of PI_TP behavior, their findings were contradictory. Additionally, scarcely did researchers report the effect sizes, meaning that little is known about the magnitude and importance of the effect of PI_TP strategies.

RQ 3 was also not fully answered. Although a few potential factors were identified, direct evidence was only garnered from Cheng et al.'s (2010) research, and most of the evidence was indirect that calls for further investigation.

\subsection{Suggestions for Future Research}

Based on the answers to research questions, this paper proposed the following issues that deserve further investigation.

- How should parents get involved in the language assessment process? Is it necessary to invite parents to engage in the assessment process through intervention programs?

- What is the conceptualization of PI_TP? What is the definition of PI_TP? Can PI_TP be just taken as a dimension of PI?

- What are the specific strategies of PI_TP under various educational backgrounds? Will the effect or frequency of these strategies change with other factors such as time or grade?

- What factors affect PI_TP? The existing studies implied that parents' perceptions of testing might affect PI_TP, and parents' perceptions of testing might consist of several dimensions. Thus, which dimension affects PI_TP? What is the nature and extent of the effect? Are there mediating factors in the process of parents' perceptions of testing affecting PI_TP behavior? Does this process get moderated by other factors?

- What is the effectiveness of PI_TP? Does PI_TP promote students' academic achievement or other aspects of learning? If yes, what about the effect size? Among various PI_TP strategies, which is most effective? 


\subsection{Test Impact on Parents' Behavior}

Taken together, there are three features concerning the impact of high-stakes language assessments on parents' behavior:

- High-stakes language assessments might influence the ways parents are involved in children's learning. Specifically, parents tend to adopt various PI_TP strategies. For example, sending children to cram schools or hiring tutors is a strategy that parents most frequently used in the test preparation period (Dawadi, 2019, 2020). In order to help children prepare for tests, parents will learn test-related knowledge through various channels, such as communicating with teachers (Holyk, 2011) or attending parent intervention programs.

- High-stakes language assessments might have a positive impact on some parents but a negative impact on others. Evidence shows that when a test provides accurate information that parents need, it will encourage more active parental involvement in children's test preparation (Vandergrift, 2015). On the other hand, tests may make parents feel extremely anxious, which in turn drives them to adopt inappropriate PI_TP strategies such as forcing their children to stay up late to prepare for tests at the cost of reducing their sleep time (Dawadi, 2019, 2020).

- High-stakes language assessments might influence some parents, but not others. For instance, in Desforges et al.'s (1994) research, some parents were engaged in test preparation, while others were not.

\section{Conclusion}

The present study has several limitations. Firstly, due to the limited number of empirical studies regarding the impact of high-stakes language assessments on parents' behavior, it did not consider the standard of peer review when screening literature, which may weaken the reliability of this study. Additionally, there is a shortage of longitudinal research, making it difficult to describe the dynamic process of the impact of high-stakes language assessments on parents' behavior. Furthermore, a few studies (e.g., Ferman, 2004) did not collect data directly from parents, rather, they gather data from other test stakeholders such as teachers and students, which might also weaken the reliability of this study. Finally, a lack of quantitative data makes it difficult to statistically describe and synthesize study outcomes.

Despite these limitations, this meta-analysis makes several contributions to test impact research. Firstly, it might be the first systematic synthesis that reveals test impact on parent behavior. Through analyzing the findings of extant literature, it identifies both direct and indirect evidence to expound whether and how parents are involved in the assessment process, the factors affecting PI in the language assessment process, and the effectiveness of such involvement. Moreover, it summarizes test impact on parents' behavior, while most of the previous research merely focused on test impact on parents' perceptions.

This research synthesis has practical implications. Firstly, it highlights the importance of exploring the impact of high-stakes language assessment on parents' involvement behavior and proposes several issues for future research. Secondly, it suggests that parents want to be involved in children's test preparation, but they do not know how to do it (Ashbaugh, 2009) so that it might be helpful to provide colorful intervention programs and materials that meet their needs.

\section{Acknowledgement}

I would like to extend my sincere and profound gratitude to my supervisor, Professor Yoshinori Watanabe, who has helped me with extradentary patience and many valuable comments. Also, I would like to express my appreciation to my senior, Dr. Makiko Kato, who has given me consistent encouragement and enlightening advice. Finally, I would like to thank my husband, without his support, this paper might not be completed.

\section{References}

Abraham, S., Wassell, B., Luet, K. M., \& Vitalone-Racarro, N. (2018). Counter engagement: Parents refusing high stakes testing and questioning policy in the era of the common core. Journal of Education Policy, 34(5), 1-24. https://doi.org/10.1080/02680939.2018.1471161

Araque, J. C., Wietstock, C., Cova, H. M., \& Zepeda, S. (2017). Impact of Latino parent engagement on student academic achievement: A pilot study. School Community Journal, 27(2), 229-250. Retrieved from https://www.schoolcommunitynetwork.org/SCJ.aspx

Ashbaugh, J. (2009). A study of the effects of parental involvement on the success of students on a high-stakes examination. (Doctoral dissertation, Duquesne University). Retrieved from https://dsc.duq.edu/etd/256 
Auerbach, S., \& Collier, S. (2012). Bringing high stakes from the classroom to the parent center lessons from an intervention program for immigrant families. Teachers College Record, 114(3), 1-40.

Barksdale-Ladd, M. A., \& Thomas, K. F. (2000). What's at stake in high-stakes testing: Teachers and parents speak out. Journal of Teacher Education, 51(5), 384-397. https://doi.org/10.1177/0022487100051005006

Birbili, M., \& Tzioga, K. (2014). Involving parents in children's assessment: Lessons from the Greek context. Early Years, 34(2), 161-174. https://doi.org/10.1080/09575146.2014.894498

Cheng, L. Y., Andrews, S., \& Yu, Y. (2010). Impact and consequences of school-based assessment (SBA): Students' and parents views of SBA in Hong Kong. Language Testing, 28(2), 221-249. https://doi.org/10.1177/0265532210384253

Chrispeels, J. H., \& Rivero, E. (2001). Engaging Latino families for student success: How parent education can reshape parents' sense of place in the education of their children. Peabody Journal of Education, 76, 119-169. https://doi.org/10.1207/S15327930pje7602_7

Clayton, G., Bingham, A. J., \& Ecks, G. B. (2019). Characteristics of the opt-out movement: Early evidence for Colorado. Education Policy Analysis Archives, 27(33), 1-30. https://doi.org/10.14507/epaa.27.4126

Cohen, J. (1988). Statistical power analysis for the behavioral sciences (2nd ed.). Hillsdale, NJ: Erlbaum.

Dawadi, S. (2019). Impact of the Secondary Education Examination (English) on students and parents in Nepal. (Doctoral dissertation, The Open University).

Dawadi, S. (2020). Parental involvement in National EFL Test preparation. RELC Journal, 51(3), 427-439. https://doi.org/10.1177/0033688219848770

Desforges, C., Holden, C., \& Hughes, M. (1994). Assessment at Key Stage One: its effects on parents, teachers and classroom practice. Research Papers in Education, 9(2), 133-158. https://doi.org/10.1080/0267152940090202

Eizadirad, A. (2020). External assessment as stereotyping: Experiences of racialized Grade 3 children, parents and educators with standardized testing in elementary schools. Review of Education, Pedagogy and Cultural Studies, 42(4), 277-295. https://doi.org/10.1080/10714413.2020.1742531

Fan, X., \& Chen, M. (2001). Parental involvement and students' academic achievement: A meta-analysis. Educational Psychology Review, 13, 1-22. https://doi.org/10.1023/A:1009048817385

Ferman, I. (2004). The washback of an EFL National Oral Matriculation Test to teaching and learning. In L. Cheng, Y. Watanabe, \& A. Curtis (Eds.), Washback in language testing: Research contents and methods (pp. 191-210). New Jersey: Lawrence Erlbaum Associates.

Fredericks, A., \& Rasinski, T. (1990). Working with Parents: Involving Parents in the Assessment Process. The Reading Teacher, 44(4), 346-349. https://doi.org/10.2307/20200642

Graue, M. E., \& Smith, S. Z. (1996). Parents and mathematics education reform: Voicing the authority of assessment. Urban Education, 30(4), 395-421. https://doi.org/10.1177/0042085996030004003

Hamilton, L., \& Brown, J. (2005). "Judgement day is coming!": Young people and the examination process in Scotland. Improving Schools, 8(1), 47-57. https://doi.org/10.1177/1365480205049339

Harris, L. R. (2015, April). Reviewing research on parent attitudes towards school assessment: Implications for classroom assessment practices. Paper presented at American Educational Research Association Annual Meeting, Chicago, Illinois. Retrieved from https://www.researchgate.net/profile/Lois-Harris/publication/276940584_Reviewing_research_on_parent_a ttitudes_towards_school_assessment_Implications_for_classroom_assessment_practices/links $/ 555 \mathrm{c} 6 \mathrm{fc} 408 \mathrm{a}$ e8f66f3ae0 $0 \mathrm{ddc} /$ Reviewing-research-on-parent-attitudes-towards-school-assessment-Implications-for-classro om-assessment-practices.pdf

Henderson, A. T., \& Mapp, K. L. (2002). A New Wave of Evidence: The Impact of School, Family, and Community Connections on Student Achievement. Annual Synthesis 2002. National Center for Family and Community Connections with Schools.

Hill, N. E., \& Tyson, D. F. (2009). Parental involvement in middle school: A meta-analytic assessment of the strategies that promote achievement. Developmental Psychology, 45(3), 740-763. https://doi.org/10.1037/a0015362 
Hill, N. E., Castellino, D. R., Lansford, J. E., Nowlin, P., Dodge, K. A., Bates, J. E., \& Pettit, G. S. (2004). Parent academic involvement as related to school behavior, achievement, and aspirations: Demographic variations across adolescence. Child Development, 75(5), 1491-1509. https://doi.org/10.1111/j.1467-8624.2004.00753.x

Holyk, T. (2011). U'h nook noh khunuk (In our own words): Lake Babine Nation parents' understanding of school assessment. (Doctoral dissertation, Simon Fraser University). Retrieved from https://summit.sfu.ca/item/12156

Hoover-Dempsey, K. V., \& Sandler, H. M. (1995). Parental involvement in children's education: Why does it make a difference? Teachers College Record, 97, 310-331.

Hoover-Dempsey, K. V., \& Sandler, H. M. (1997). Why do parents become involved in their children's education? Review of Educational Research, 67, 3-42. https://doi.org/10.3102/00346543067001003

Madaus, G., \& Russell, M. (2010). The paradoxes of high stakes testing. Journal of Education, 190, 21-30. https://doi.org/10.1177/0022057410190001-205

Martínez, R.-A., Martínez, R., \& Pérez, M. H. (2004). Children's school assessment: Implications for family-school partnerships. International Journal of Educational Research, 41(1), 24-39. https://doi.org/10.1016/j.jier.2005.04.004

Osburn, M. Z., Stegman, C., Suitt, L. D., \& Ritter, G. (2004). Parents' perceptions of standardised testing: Its relationship and effect on student achievement. Journal of Educational Research and Policy Studies, 4(1), 75-95.

Paladino, M. (2020). Towards an understanding of the testing opt-out movement: Why parents choose to opt-out or opt-in. Journal for Leadership and Instruction, 19(2), 14-18.

Pizmony-Levy, O., \& Saraisky, N. G. (2016). Who opts out and why? Results from a national survey on opting out of standardized tests. Teachers College, Columbia University. Retrieved from https://www.tc.columbia.edu/media/news/docs/Opt_Out_National-Survey----FINAL-FULL-REPORT.pdf

Reta, E. K. (2017). The impact of high stake EFL tests on the role of teachers, learners and parents. English for Specific Purposes World, 53, 1-19.

Rutland, J., \& Hall, A. H. (2013). Involving families in the assessment [Unpublished manuscript]. Clemson University.

Retrieved

from

https://tigerprints.clemson.edu/cgi/viewcontent.cgi?referer=https://scholar.google.com/\&httpsredir=1\&artic le $=1024 \&$ context $=$ eugene_pubs

Safari, P. (2016). Reconsideration of language assessment is a MUST for democratic testing in the educational system of Iran. Interchange: A Quarterly Review of Education, 47(3), 267-296. https://doi.org/10.1007/s10780-016-9276-8

Saville, N., \& Khalifa, H. (2016). The impact of language assessment. In D. Tsagari \& J. Banerjee (Eds.), The handbook of second language assessment (pp. 77-94). Walter de Gruyter Inc. https://doi.org/10.1515/9781614513827-008

Schroeder, S., Currin, E., \& McCardle, T. (2016). Mother tongues: The opt out movement's vocal response to patriarchal education reform. Gender \& Education, 30(8), 1001-1018. https://doi.org/10.1080/09540253.2016.1270422

Schroeder, S., Currin, E., \& McCardle, T. (2020a). "We're kind of at a pivotal point": Opt Out's vision for an ethic of care in a post-neoliberal era. Policy Futures in Education, 18(1), 138-158. https://doi.org/10.1177/1478210318758813

Schroeder, S., Currin, E., \& McCardle, T. (2020b). 'Solidarity, sisters! We're all crazy': The moral madness of opting out of high-stakes testing. Educational Studies: Journal of the American Educational Studies Association, 56(4), 347-365. https://doi.org/10.1080/00131946.2020.1757447

Scott, C. (2007). Stakeholder perceptions of test impact. Assessment in Education: Principles, Policy \& Practice, 14(1), 27-49. https://doi.org/10.1080/09695940701272807

Tsagari, D., \& Cheng, L. (2017). Washback, impact, and consequences revisited. In E. Shohamy, I. G. Or, \& S. May (Eds.), Language Testing and Assessment (3rd ed., pp. 359-372). Cham, Switzerland: Springer International Publishing AG. https://doi.org/10.1007/978-3-319-02261-1_24 
Vandergrift, L. (2015). The DELF in Canada: Perceptions of students, teachers, and parents. Canadian Modern Language Review, 71(1), 52-74. https://doi.org/10.3138/cmlr.1752

Walker, J. M. T. (2016). Realizing the American dream: A parent education program designed to increase Latino family engagement in children's Education. Journal of Latinos and Education, 15(4), 344-357. https://doi.org/10.1080/15348431.2015.1134536

Wenham, L. (2019). 'It was deathly dull and boring and stressful': Listening to parents' voices on primary school testing. FORUM, 61(3), 415-426. https://doi.org/10.15730/forum.2019.61.3.415

Wolfendale, S. (1998). Assisting parents with child and adolescent development: Involving parents in child assessments in the United Kingdom. Childhood Education, 74(6), 355-358. https://doi.org/10.1080/00094056.1998.10521149

\section{Note}

Note 1. Test and assessment are used interchangeably in this paper.

\section{Copyrights}

Copyright for this article is retained by the author(s), with first publication rights granted to the journal.

This is an open-access article distributed under the terms and conditions of the Creative Commons Attribution license (http://creativecommons.org/licenses/by/4.0/). 